\title{
Antimicrobial activity of the crude extracts and five flavonoids from the twigs of Dorstenia barteri (Moraceae)
}

\begin{abstract}
Armelle Tsafack Mbaveng ${ }^{\mathrm{a}}$, Bathélémy Ngameni ${ }^{\mathrm{b}}$, Victor Kuete ${ }^{\mathrm{a}}$, Ingrid Konga Simo ${ }^{\mathrm{b}}$, Pantaléon Ambassa ${ }^{b}$, René Roy ${ }^{c}$, Merhatibeb Bezabih ${ }^{\mathrm{d}}$, François-Xavier Etoa ${ }^{\mathrm{a}}$, Bonaventure Tchaleu Ngadjui ${ }^{\mathrm{b}}$, Berhanu M. Abegaz ${ }^{\mathrm{d}}$, J.J. Marion Meyer ${ }^{\mathrm{e}}$, Namrita Lall ${ }^{\mathrm{e}}$ and Véronique Penlap Beng ${ }^{\mathrm{a}}$
\end{abstract}

${ }^{a}$ Department of Biochemistry, Faculty of Science, University of Yaoundé I, B.P. 812 Yaoundé, Cameroon

${ }^{b}$ Department of Organic Chemistry, Faculty of Science, University of Yaoundé I, B.P. 812 Yaoundé, Cameroon

${ }^{c}$ Département de Chimie, Université du Québec à Montréal, Montréal, 2101 JeanneMance, CP 8888, Succ. Centre-ville, Que., Canada H3C 3P8

${ }^{\mathrm{d}}$ Department of Chemistry, Faculty of Science, University of Botswana, Private bag 00704, Gaberone, Botswana

${ }^{\mathrm{e}}$ Department of Plant Science, Faculty of Agricultural and Biological Science, University of Pretoria, Pretoria 0002, South Africa

\section{Abstract}

The aim of this study was to evaluate the antimicrobial activity of the crude extract of the twigs of Dorstenia barteri (DBT) as well as that of four of the five flavonoids isolated from this extract. Gram-positive bacteria (six species), Gram-negative bacteria (12 species) and fungi (four species) were used. The agar disc diffusion test was used to determine the sensitivity of the tested samples while the well micro-dilution was used to determine the minimal inhibition concentrations (MIC) and the minimal microbicidal concentration $(\mathrm{MMC})$ of the active samples. The results of the disc diffusion assay 
showed that DBT, isobavachalcone (1), and kanzonol C (4) prevented the growth of all the 22 tested microbial species. Other compounds showed selective activity. The inhibitory activity of the most active compounds namely compounds $\mathbf{1}$ and $\mathbf{4}$ was noted on $86.4 \%$ of the tested microorganisms and that of 4-hydroxylonchocarpin (3) was observed on $72.7 \%$. This lowest MIC value of $19.06 \mu \mathrm{g} / \mathrm{ml}$ was observed with the crude extract on seven microorganisms namely Citrobacter freundii, Enterobacter aerogens, Proteus mirabilis, Proteus vulgaris, Bacillus megaterium, Bacillus stearothermophilus and Candida albicans. For the tested compounds, the lowest MIC value of $0.3 \mu \mathrm{g} / \mathrm{ml}$ (on six of the 22 organisms tested) was obtained only with compound $\mathbf{1}$, which appeared as the most active compound. This lowest MIC value $(0.3 \mu \mathrm{g} / \mathrm{ml})$ is about 4-fold lower than that of the RA, indicating the powerful and very interesting antimicrobial potential of isobavachalcone (1). The antimicrobial activities of DBT, as well as that of compounds $\mathbf{1}$, 3,4 , amentoflavone (5) are being reported for the first time. The overall results provide promising baseline information for the potential use of the crude extracts from DBT as well as some of the isolated compounds in the treatment of bacterial and fungal infections.

\section{Abbreviations}

CLED agar, cystine-lactose-electrolyte deficient agar; $\mathrm{CFU}$, colony forming unit; $\mathrm{CH}_{2} \mathrm{Cl}_{2}$, dichloromethane; $\mathrm{CHCl}_{3}$, chloroform; Compound 1, isobavachalcone; Compound 2, stipulin; Compound 3, 4-hydroxylonchocarpin; Compound 4, kanzonol C; Compound 5, amentoflavone; DBT, Dorstenia barteri; DMSO, dimethylsulfoxide; EtOAc, ethyl acetate; IZ, inhibition zone; LMP, laboratory of applied microbiology and molecular pharmacology; $\mathrm{MeOH}$, methanol; MHA, Mueller Hinton agar; MIC, minimal inhibition concentration; $\mathrm{MMCm}$, inimal microbicidal concentration; $\mathrm{MW}$, molecular weight; NA, nutrient agar; NBGP, nutrient broth containing $0.05 \%$ phenol red and supplemented with $10 \%$; NMR, nuclear magnetic resonance; RA, reference antibiotics; SDA, sabouraud dextrose agar; PSM, pseudomonas selective medium; SS agar, Salmonella-Shigella agar; TLC, thin layer chromatography 


\section{Article Outline}

1. Introduction

2. Methodology

2.1. Plant material

2.2. Isolation and general procedures

2.3. Microbial strains

2.4. Antimicrobial assays

2.4.1. Culture media and microbial identification

2.4.2. Chemicals

2.4.3. Sensitivity test: agar disc diffusion assay

2.4.3.1. Preparation of discs

2.4.3.2. Diffusion test

2.4.4. MIC and MMC determination

3. Results and discussion

Acknowledgements

References

\section{Introduction}

The plants of the genus Dorstenia are traditionally used in African and South American folk medicine in the treatment of many illnesses such as snakebite, rheumatic, infectious diseases, arthritis ([Bouquet, 1969], [Adjanohoun et al., 1996], [Abegaz et al., 2000] and [Kuete et al., 2007a]). In Cameroon, the leaves and twigs of Dorstenia barteri Bureau are used as decoction in the treatment of mumps, yaws and infected wounds ([Thomas et al., 1989], [Abegaz et al., 1998] and [Tsopmo et al., 1999]). This genus is a rich source of flavonoids such as prenylated and geranylated chalcones, and coumarins ([Abegaz et al., 2004] and [Ngameni et al., 2007]). The antimicrobial potency of the above secondary metabolite classes has been demonstrated ([Bruneton, 1999] and [Cowan, 1999]). In our research group, many compounds with significant pharmacological effects have been isolated from the genus Dorstenia. Many Chalcones isolated from Dorstenia barteri namely isobavachalcone, paratocarpin $\mathrm{C}$, stipulin, and dorsmannin $\mathrm{A}$ inhibited the 
proliferation of the brain tumour derived U87 glioblastoma cells (Ngameni et al., 2007). Stipulin and other flavonoids isolated from the twigs of Dorstenia angusticornis (gancaonin $\mathrm{Q}$, angusticornin $\mathrm{B}$, and bartericin $\mathrm{A}$ ) were also found to be very active on bacteria and yeasts associated to human pathologies (Kuete et al., 2007a). In our continuous herbal drug research program from medicinal plants from the genus Dorstenia, we undertook to evaluate the antimicrobial potency of the crude extracts from the twigs of Dorstenia barteri Bureau var. multiradiata as well as that of the compounds isolated from this extract against the wide range of microorganisms implicated in infectious diseases.

\section{Methodology}

\subsection{Plant material}

The twigs of Dorstenia barteri Bureau var. multiradiata were collected in March 2003 in Kumba, South West province of Cameroon. The botanical identification of the plants was done by the National Herbarium in Yaounde, where the voucher specimen is conserved under the reference number 44016/HNC.

\subsection{Isolation and general procedures}

The air-dried and powdered twigs of Dorstenia barteri Bureau var. multiradiata $(1 \mathrm{~kg})$ were macerated in either a mixture of $\mathrm{CH}_{2} \mathrm{Cl}_{2} / \mathrm{MeOH}(1: 1)$ or in $\mathrm{MeOH}$ for 24 and $2 \mathrm{~h}$, respectively, at room temperature. These two extracts were then combined. Removal of the solvent from the combined extracts under reduced pressure yielded $45 \mathrm{~g}$ of a dark green residue that constituted the crude extract. A mass of $40 \mathrm{~g}$ of this organic extract was submitted to flash liquid chromatography on silica gel $60(220 \mathrm{~g})$ and eluted with hexane-ethyl acetate gradients: (3:1), (1:1), (1:3), and finally with pure EtOAc to give 40 fractions of $250 \mathrm{ml}$ each. These fractions were monitored by TLC and the fractions showing similar ${ }^{1} \mathrm{H}$ NMR spectra were combined. Fractions 1-20 (10 g), obtained with $(3: 1, \mathrm{v} / \mathrm{v})$ hexane-EtOAc were subjected to column chromatography over silica gel using hexane-EtOAc as eluent with a continuous gradient (95:5 to 7:3, v/v), followed by gel filtration chromatography over Sephadex $\mathrm{LH}-20$ using $\mathrm{CHCl}_{3}-\mathrm{MeOH}(2: 1)$ as eluent. The post-chlorophyll fractions were combined and purified successively on column 
chromatography followed by preparative TLC to yield: isobavachalcone (1, $98 \mathrm{mg}$, MW: 324, mp: 171-172) (Abegaz et al., 1998) and stipulin (2, 20 mg, MW: 392, mp: 122-123) (Abegaz et al., 1998). Combined fractions 21-40 (25 g) obtained from the (1:1) to (1:3) hexane-EtOAc mixtures and pure EtOAc were subjected successively to silica gel column chromatography and preparative TLC, eluting with solvent mixtures of increasing polarity (from $\mathrm{CH}_{2} \mathrm{Cl}_{2}$ to $96: 4$ (v/v) $\mathrm{CH}_{2} \mathrm{Cl}_{2}-\mathrm{MeOH}$ ). The fractions eluted with $\mathrm{CH}_{2} \mathrm{Cl}_{2}$ gave, after repeated preparative TLC, 4-hydroxylonchocarpin (3, $45 \mathrm{mg}, \mathrm{MW}$ : 322, mp: 207-208) (Ngadjui et al., 2000). Those eluted with $\mathrm{CH}_{2} \mathrm{Cl}_{2}-\mathrm{MeOH}$ (96:4) gave kanzonol C (4, 125 mg, MW: 392, mp: 190-194) (Fukai et al., 1994), and amentoflavone (5, 40 mg, MW: 554, mp: 247-248) ([Goh et al., 1992] and [Shih et al., 2004]), after repeated preparative TLC.

Aluminium sheet pre-coated with silica gel $60 \mathrm{GF}_{254}$ Merck was used for thin layer chromatography and the isolated spots were visualized using both ultra-violet light (254 and $366 \mathrm{~nm}$ ) and by spraying with ammonium molybdate solution and heating. The chemical structures of each of the isolated compounds was determined on the basis of spectral data produced by one and two-dimensional nuclear magnetic resonance (NMR), recorded on Brüker AMX-500 or on Varian Gemini-300 spectrometers. ESIMS were recorded on a Micromass Quattro LC mass spectrometer. The chemical structures of the compounds isolated from Dorstenia barteri Bureau var. multiradiata are given in Fig. 1.

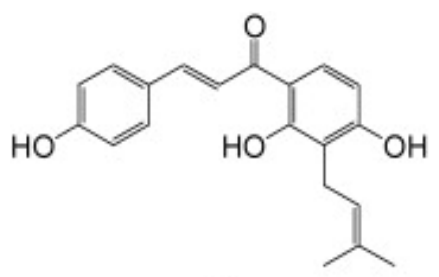

1

isobavachalcone

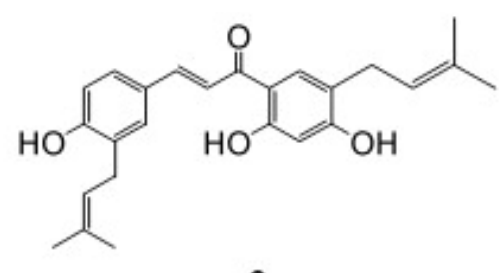

2

stipulin

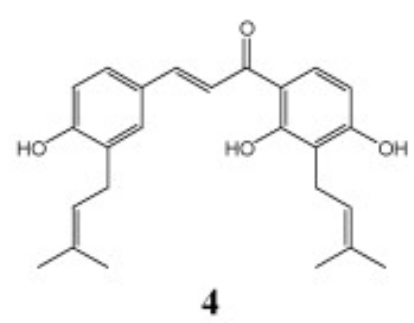

kanzonol C

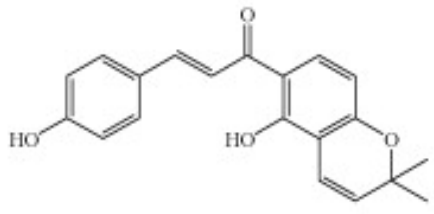

3

4-hydroxylonchocarpin<smiles>O=C1CC(O)C2Oc3cc(O)cc(O)c3C(=O)C12c1c(-c2c(O)ccc(O)c2O)ccc(O)c1O</smiles>

amentoflavone 
Fig. 1. Chemical structures of compounds isolated from the twigs of Dorstenia barteri Bureau var. multiradiata.

\subsection{Microbial strains}

Twenty-two of microorganisms namely Bacillus cereus, Bacillus megaterium, Bacillus stearothermophilus, Bacillus subtilis, Staphylococcus aureus, Streptococcus faecalis (Gram-positive bacteria), Escherichia coli, Shigella dysenteriae, Proteus vulgaris, Proteus mirabilis, Shigella flexneri, Klebsiella pneumoniae, Pseudomonas aeruginosa, Salmonella typhi, Morganella morganii, Enterobacter aerogens, Citrobacter freundii, Enterobacter cloacae (Gram-negative bacteria), Candida albicans, Candida gabrata, Microsporum audorium, Trichophyton rubrum (fungi) were used in this study. 'Institut Appert de Paris' provided three Bacillus species, while the A.F.R.C Reading Laboratory of Great Britain provided Bacillus cereus. Other strains were clinical isolates from 'Centre Pasteur of Cameroon', Yaoundé. The microbial isolates were maintained on agar slant at $4{ }^{\circ} \mathrm{C}$ in the Laboratory of Applied Microbiology and Molecular Pharmacology (LMP) (Faculty of Science, University of Yaoundé I) where the antimicrobial tests were performed. The strains were sub-cultured on a fresh appropriate agar Plate $24 \mathrm{~h}$ prior to any antimicrobial test.

\subsection{Antimicrobial assays}

\subsubsection{Culture media and microbial identification}

Nutrient agar (NA) (Oxoid) containing bromocresol purple was used for the activation of Bacillus species ([Marchal et al., 1985] and [Kuete et al., 2008]), while NA was used for other bacteria. Sabouraud glucose agar (Oxoid) was used for the activation of the fungi. The Mueller Hinton agar (MHA)(Oxoid) was used in sensitivity assay. Nutrient broth containing $0.05 \%$ phenol red and supplemented with $10 \%$ glucose (NBGP) was used for MIC and MMC determinations.

The identify of the tested microbial species was confirmed before use at our laboratory (LMP) by culturing on the specific media followed by biochemical test using automate microbiological system in identification (API system): Salmonella and Shigella sp. (SS 
agar; API 20E) (bioMérieux), Escherichia coli, Shigella dysenteriae, Proteus sp., Klebsiella pneumoniae, Morganella morganii, Citrobacter freundi and Enterobacter sp. (C.L.E.D agar; API20E) (bioMérieux), Pseudomonas aeruginosa (PSM agar, API20E) (bioMérieux), Staphylococcus aureus [Chapman agar; API 32 Staph) (bioMérieux)], Streptococcus faecalis [Columbia Agar; API20strept) (bioMérieux)], Bacillus sp. [NA (Oxoid) containing bromocresol purple; API $50 \mathrm{CH}$ (bioMérieux)], Candida sp. [Chromagar ${ }^{\mathrm{TM}}$ Candida (Becton-Dickinson); API 20C AUX (bioMérieux)], Microsporum audorium and Trichophyton rubrum [SDA 1\% chloramphenicol; API20C) (bioMérieux)] (Marchal et al., 1985).

\subsubsection{Chemicals}

Nystatin (Maneesh Pharmaceutic Pvt. Ltd., Govandi, Mumbai 400043, India) and gentamicin (Jinling Pharmaceutic (Group) corp., Zhejang Tieng Feng Pharmaceutic Factory, No. 11 Chezhan Road, Huzhou city, Zhejang, China) were used as reference antibiotics (RA) against fungi and bacteria, respectively. The dimethylsulfoxide (DMSO)(SIGMA) was used as solvent for the tested samples. 


\subsubsection{Sensitivity test: agar disc diffusion assay}

\subsubsection{Preparation of discs}

Whatmann filter paper (No.1) discs of $6 \mathrm{~mm}$ diameter were impregnated with $10 \mu \mathrm{l}$ of the solution of crude extract (at $20 \mathrm{mg} / \mathrm{ml}$ ) or isolated compound (at $5 \mathrm{mg} / \mathrm{ml}$ ) prepared using DMSO. The discs were evaporated at $37^{\circ} \mathrm{C}$ for $24 \mathrm{~h}$. The RA discs (gentamycin for bacteria and nystatin for fungi) were prepared as described above using the appropriate concentrations to obtain discs containing $50 \mu \mathrm{g}$ of drug. Two discs were prepared for each sample.

\subsubsection{Diffusion test}

The antimicrobial diffusion test was carried out as described by Berghe and Vlietinck (1991) using a cell suspension of about $1.5 \times 10^{6} \mathrm{CFU} / \mathrm{ml}$ obtained from a McFarland turbidity standard No. 0.5 . The suspension was standardised by adjusting the optical density to 0.1 at $600 \mathrm{~nm}$ (SHIMADZU UV-120-01 spectrophotometer) (Tereschuk et al., 1997). This was used to inoculate by flooding the surface of MHA plates. Excess liquid was air-dried under a sterile hood and the impregnated discs applied at equidistant points on top of the agar medium. A disc prepared with only the corresponding volume of DMSO was used as negative control. The plates were incubated at $37^{\circ} \mathrm{C}$ for $24 \mathrm{~h}$. Antimicrobial activity was evaluated by measuring the diameter of the inhibition zone (IZ) around the disc. The assay was repeated twice and the results expressed using the following symbols: $(-)$ for no activity and $(+)$ for samples with IZ $>6 \mathrm{~mm}$.

\subsubsection{MIC and MMC determination}

The MICs of test samples and RA were determined as follows: the test sample was first of all dissolved in DMSO. The solution obtained was added to the NBGP to a final concentration of $156.3 \mu \mathrm{g} / \mathrm{ml}$ for the crude extracts and $39.1 \mu \mathrm{g} / \mathrm{ml}$ for the compounds and RA. This was serially diluted 2 -fold to obtain concentration ranges of $1.2-$ $156.3 \mu \mathrm{g} / \mathrm{ml}$ for the crude extracts and $0.08-39.1 \mu \mathrm{g} / \mathrm{ml}$ for the compounds and RA. One hundred microlitres of each concentration was added in a well (96-wells microplate) containing $95 \mu \mathrm{l}$ of NBGP and $5 \mu \mathrm{l}$ of the standard inoculum. The final concentration of DMSO in the well was less than $1 \%$ (preliminary analyses with $1 \%(\mathrm{v} / \mathrm{v})$ DMSO/NBGP 
affected neither the growth of the test organisms nor the change of colour due to this growth). The negative control well consisted of $195 \mu \mathrm{l}$ of NBGP and $5 \mu \mathrm{l}$ of the standard inoculum ([Zgoda and Porter, 2001] and [Kuete et al., 2007b]). The plates were covered with a sterile plate sealer, then agitated to mix the content of the wells using a plate shaker and incubated at $37^{\circ} \mathrm{C}$ for $24 \mathrm{~h}$. The assay was repeated trice. Microbial growth was determined by observing the change of colour in the wells (red when there is no growth and yellow when there is growth). The lowest concentration showing no colour change was considered as the MIC.

For the determination of the MMC, a portion of liquid $(5 \mu \mathrm{l})$ from each well that showed no change in colour was plated on MHA and incubated at $37^{\circ} \mathrm{C}$ for $24 \mathrm{~h}$. The lowest concentration that yielded no growth after this sub-culturing was taken as the MMC.

\section{Results and discussion}

The structures of the isolated compounds were established using spectroscopic analysis, especially, NMR spectra in conjunction with 2D experiments, COSY, HMQC and HMBC, and direct comparison with published information and with authentic specimens obtained previously in our research group for some cases. The compounds isolated from the twigs of Dorstenia barteri Bureau (Fig. 1) were five flavonoids identified as isobavachalcone (1), stipulin (2), 4-hydroxylonchocarpin (3), kanzonol C (4) and amentoflavone (5). Compounds 1 to $\mathbf{4}$ belong to the sub-class of chlacones and compound 5 is a biflavone. The isolation of Stipulin from other species of Dorstenia namely Dorstenia angusticornis was reported in our previous study (Kuete et al., 2007a). The antimicrobial potency of Stipulin as well as that of many natural occurring chalcones, flavones and coumarins is well documented ([Cowan, 1999], [Kuete et al., 2007a], [Kuete et al., 2007b] and [Kuete et al., 2008]). In this study, the antibacterial and

antifungal activities of the crude extract and compounds 1, 3, 4 and 5 were evaluated and the results are reported in Table 1 and Table 2. 
Table 1.

Antimicrobial activity a of the crude extracts, compounds isolated from the twigs of

Dorstenia barteri Bureau and reference antibiotics determined by the disc diffusion test

\begin{tabular}{|c|c|c|c|c|c|c|}
\hline \multirow[t]{2}{*}{ Microorganisms } & \multicolumn{6}{|c|}{ Tested samples $^{b}$} \\
\hline & DBT & 1 & 3 & 4 & 5 & RA \\
\hline \multicolumn{7}{|l|}{ Gram-negative bacteria } \\
\hline Citrobacter freundii LMP0804G & + & + & + & + & - & + \\
\hline Enterobacter aerogens LMP1004G & + & + & + & + & + & + \\
\hline Enterobacter cloacae LMP1104G & + & + & + & + & + & + \\
\hline Escherichia coli LMP0101U & + & + & - & + & - & + \\
\hline Klebsiella pneumoniae LMP0210U & + & + & - & + & - & + \\
\hline Morganella morganii LMP0904G & + & + & + & + & - & + \\
\hline Proteus mirabilis LMP0504G & + & + & + & + & - & + \\
\hline Proteus vulgaris LMP0103U & + & + & + & + & + & + \\
\hline Pseudomonas aeruginosa LMP0102U & + & + & - & + & - & + \\
\hline Shigella dysenteriae LMP0208U & + & + & - & + & + & + \\
\hline Shigella flexneri LMP0313U & + & + & + & + & - & + \\
\hline Salmonella typhi LMP0209U & + & + & - & + & - & + \\
\hline LMP0206U & & & & & & \\
\hline
\end{tabular}

Gram-positive bacteria 


\begin{tabular}{|c|c|c|c|c|c|c|}
\hline \multirow[t]{2}{*}{ Microorganisms } & \multicolumn{6}{|c|}{ Tested samples ${ }^{\mathrm{b}}$} \\
\hline & DBT & 1 & 3 & 4 & 5 & RA \\
\hline Streptococcus faecalis LMP0207U & + & + & + & + & - & + \\
\hline Staphylococcus aureus LMP0206U & + & + & + & + & - & + \\
\hline Bacillus cereus LMP0404G & + & + & + & + & + & + \\
\hline Bacillus megaterium LMP0204G & + & + & + & + & + & + \\
\hline Bacillus stearothermophilus LMP0104G & + & + & + & + & + & + \\
\hline Bacillus subtilis LMP0304G & + & + & + & + & + & + \\
\hline \multicolumn{7}{|l|}{ Fungi } \\
\hline Candida albicans LMP0204U & + & + & + & + & + & + \\
\hline Candida gabrata LMP0413U & + & + & + & + & + & + \\
\hline Microsporum audorium LMP0725D & + & + & + & + & - & + \\
\hline Trichophyton rubrum LMP0723D & + & + & + & + & + & + \\
\hline
\end{tabular}

$(-)$ : Not active; $(+)$ : active.

${ }^{\text {a }}$ Antimicrobial activity: crude extracts were tested at $200 \mu \mathrm{g} / \mathrm{disc}$ and compounds at $50 \mu \mathrm{g} /$ disc.

${ }^{\mathrm{b}}$ Tested samples: crude extracts from the twigs of Dorstenia barteri (DBT); compounds isolated from DBT [1: isobavachalcone; 3: 4-hydroxylonchocarpin, 4: kanzonol C, 5: amentoflavone]; RA: Reference antibiotics (gentamycin for bacteria, nystatin for yeasts). 
Table 2.

Minimum inhibition concentrations $(\mu \mathrm{g} / \mathrm{ml})$ and minimum microbicidal concentrations $(\mu \mathrm{g} / \mathrm{ml})$ of the crude extracts ${ }^{\mathbf{a}}$, compounds isolated from the twigs of Dorstenia barteri Bureau ${ }^{\mathbf{b}}$ and reference antibiotics ${ }^{\mathbf{c}}$

\begin{tabular}{|c|c|c|c|c|c|c|c|c|c|c|c|c|}
\hline \multirow{2}{*}{$\begin{array}{l}\text { Microorganis } \\
\text { ms }\end{array}$} & \multicolumn{6}{|c|}{ Minimum inhibition concentrations } & \multicolumn{6}{|c|}{ Minimum microbicidal concentrations } \\
\hline & DBT & 1 & 3 & 4 & 5 & RA & DBT & 1 & 3 & 4 & 5 & RA \\
\hline \multicolumn{13}{|c|}{ Gram-negative bacteria } \\
\hline $\begin{array}{l}\text { Citrobacter } \\
\text { freundii }\end{array}$ & 19.5 & $>39.1$ & $>39.1$ & $>39.1$ & - & 4.9 & 39.1 & nd & nd & nd & - & 9.8 \\
\hline $\begin{array}{l}\text { Enterobacter } \\
\text { aerogens }\end{array}$ & 19.5 & 0.6 & 4.9 & 4.9 & 39.1 & 9.8 & 78.1 & 1.2 & 39.1 & 19.5 & $>39.1$ & 19.5 \\
\hline $\begin{array}{l}\text { Enterobacter } \\
\text { cloacae }\end{array}$ & 39.1 & 0.3 & 1.2 & 4.9 & 39.1 & 4.9 & 78.1 & 0.6 & 9.8 & 19.5 & $>39.1$ & 9.8 \\
\hline $\begin{array}{l}\text { Escherichia } \\
\text { coli }\end{array}$ & 78.1 & 39.1 & - & 39.1 & - & 1.2 & 156.3 & $>39.1$ & - & $>39.1$ & - & 4.9 \\
\hline $\begin{array}{l}\text { Klebsiella } \\
\text { pneumoniae }\end{array}$ & 78.1 & 39.1 & - & 39.1 & - & 2.4 & 156.3 & $>39.1$ & - & $>39.1$ & - & 2.4 \\
\hline Morganella & 78.1 & 0.6 & 1.2 & 4.9 & - & 2.4 & 156.3 & 1.2 & 9.8 & 9.8 & - & 2.4 \\
\hline
\end{tabular}




\begin{tabular}{|c|c|c|c|c|c|c|c|c|c|c|c|c|}
\hline \multirow{2}{*}{$\begin{array}{l}\text { Microorganis } \\
\text { ms }\end{array}$} & \multicolumn{6}{|c|}{ Minimum inhibition concentrations } & \multicolumn{6}{|c|}{ Minimum microbicidal concentrations } \\
\hline & DBT & 1 & 3 & 4 & 5 & RA & DBT & 1 & 3 & 4 & 5 & $\mathbf{R A}$ \\
\hline \multicolumn{13}{|l|}{ morganii } \\
\hline $\begin{array}{l}\text { Proteus } \\
\text { mirabilis }\end{array}$ & 19.5 & 1.2 & 39.1 & 9.8 & - & 2.4 & 39.1 & 4.9 & $>39.1$ & 19.5 & - & 2.4 \\
\hline $\begin{array}{l}\text { Proteus } \\
\text { vulgaris }\end{array}$ & 19.5 & 1.2 & 39.1 & 9.8 & 19.5 & 1.2 & 39.1 & 4.9 & $>39.1$ & 19.5 & 39.1 & 4.9 \\
\hline $\begin{array}{l}\text { Pseudomonas } \\
\text { aeruginosa }\end{array}$ & 78.1 & 39.1 & - & 39.1 & - & 4.9 & 156.3 & $>39.1$ & - & $>39.1$ & - & 9.8 \\
\hline $\begin{array}{l}\text { Shigella } \\
\text { dysenteriae }\end{array}$ & 78.1 & $>39.1$ & - & $>39.1$ & 39.1 & 2.4 & 156.3 & nd & - & nd & $>39.1$ & 2.4 \\
\hline $\begin{array}{l}\text { Shigella } \\
\text { flexneri }\end{array}$ & 39.1 & 0.6 & 4.9 & 4.9 & - & 2.4 & 78.1 & 1.2 & 9.8 & 9.8 & - & 2.4 \\
\hline $\begin{array}{l}\text { Salmonella } \\
\text { typhi }\end{array}$ & 156.3 & $>39.1$ & - & $>39.1$ & - & 2.4 & $>156.3$ & nd & - & nd & - & 2.4 \\
\hline
\end{tabular}




\begin{tabular}{|c|c|c|c|c|c|c|c|c|c|c|c|c|}
\hline \multirow{2}{*}{$\begin{array}{l}\text { Microorganis } \\
\text { ms }\end{array}$} & \multicolumn{6}{|c|}{ Minimum inhibition concentrations } & \multicolumn{6}{|c|}{ Minimum microbicidal concentrations } \\
\hline & DBT & 1 & 3 & 4 & 5 & RA & DBT & 1 & 3 & 4 & 5 & $\mathbf{R A}$ \\
\hline \multicolumn{13}{|c|}{ Gram-positive bacteria } \\
\hline $\begin{array}{l}\text { Streptococcu } \\
\text { s faecalis }\end{array}$ & 39.1 & 0.3 & 4.9 & 4.9 & - & 4.9 & 78.1 & 0.6 & 9.8 & 9.8 & - & 9.8 \\
\hline $\begin{array}{l}\text { Staphylococc } \\
\text { us aureus }\end{array}$ & 78.1 & 0.3 & 4.9 & 39.1 & - & 2.4 & 156.3 & 0.6 & 9.8 & $>39.1$ & - & 2.4 \\
\hline $\begin{array}{l}\text { Bacillus } \\
\text { cereus }\end{array}$ & 78.1 & 0.6 & 4.9 & 9.8 & 39.1 & 1.2 & 156.3 & 1.2 & 9.8 & 19.5 & $>39.1$ & 4.9 \\
\hline $\begin{array}{l}\text { Bacillus } \\
\text { megaterium }\end{array}$ & 19.5 & 0.6 & 1.2 & 4.9 & 39.1 & 2.4 & 78.1 & 1.2 & 4.9 & 19.5 & $>39.1$ & 2.4 \\
\hline $\begin{array}{l}\text { Bacillus } \\
\text { stearothermo } \\
\text { philus }\end{array}$ & 19.5 & 0.3 & 1.2 & 4.9 & 39.1 & 4.9 & 156.3 & 0.6 & 4.9 & 19.5 & $>39.1$ & 9.8 \\
\hline $\begin{array}{l}\text { Bacillus } \\
\text { subtilis }\end{array}$ & 78.1 & 0.6 & 4.9 & 9.8 & 39.1 & 1.2 & 156.3 & 1.2 & 9.8 & 19.5 & $>39.1$ & 4.9 \\
\hline
\end{tabular}




\begin{tabular}{|c|c|c|c|c|c|c|c|c|c|c|c|c|}
\hline \multirow{2}{*}{$\begin{array}{l}\text { Microorganis } \\
\text { ms }\end{array}$} & \multicolumn{6}{|c|}{ Minimum inhibition concentrations } & \multicolumn{6}{|c|}{ Minimum microbicidal concentrations } \\
\hline & DBT & 1 & 3 & 4 & 5 & $\mathbf{R A}$ & DBT & 1 & 3 & 4 & 5 & $\mathbf{R A}$ \\
\hline \multicolumn{13}{|l|}{ Fungi } \\
\hline $\begin{array}{l}\text { Candida } \\
\text { albicans }\end{array}$ & 19.5 & 0.3 & 4.9 & 4.9 & 39.1 & 2.4 & 156.3 & 0.6 & 19.5 & 19.5 & $>39.1$ & 2.4 \\
\hline $\begin{array}{l}\text { Candida } \\
\text { gabrata }\end{array}$ & 78.1 & 0.3 & 4.9 & 4.9 & 39.1 & 2.4 & 156.3 & 0.6 & 19.5 & 19.5 & $>39.1$ & 2.4 \\
\hline $\begin{array}{l}\text { Microsporum } \\
\text { audorium }\end{array}$ & 78.1 & 1.2 & 9.8 & 9.8 & - & 4.9 & 156.3 & 4.9 & 19.5 & 39.1 & - & 9.8 \\
\hline $\begin{array}{l}\text { Trichophyton } \\
\text { rubrum }\end{array}$ & 156.3 & 1.2 & 4.9 & 39.1 & 39.1 & 1.2 & $>156.3$ & 4.9 & 9.8 & $>39.1$ & $>39.1$ & 4.9 \\
\hline
\end{tabular}

nd: Not determined because MIC not determined; (-): not tested because samples were not active by disc diffusion. 
${ }^{a}$ Crude extracts from the twigs of Dorstenia barteri Bureau (DBT).

${ }^{\mathrm{b}}$ Tested compounds isolated from DBT [1: isobavachalcone; 3: 4-hydroxylonchocarpin, 4: kanzonol C, 5: amentoflavone].

${ }^{\mathrm{c}} \mathrm{RA}$ : Reference antibiotics [gentamycin for bacteria, nystatin for yeasts].

From the results of the disc diffusion assay (Table 1), it appeared that the crude extracts from Dorstenia barteri Bureau (at $200 \mu \mathrm{g} / \mathrm{disc}$ ), compounds 1 and 4 (at $50 \mu \mathrm{g} / \mathrm{disc}$ ) prevented the growth of all the 22 tested microbial species. Other compounds showed selective activity, their inhibition effects being noted on $17(77.3 \%)$ and $11(50 \%)$ of the 22 tested microorganisms respectively for compounds $\mathbf{3}$ and 5. Apart from compounds $\mathbf{1}$ and 4, no other tested compound was active on all the Gram-negative bacteria. Compounds 1, 3 and $\mathbf{4}$ were active on all the Gram-positive bacteria and the four tested fungi (Table 1).

The MIC values ranged from 19.5 to $156.3 \mu \mathrm{g} / \mathrm{ml}$ (Table 2) the crude extract from Dorstenia barteri Bureau on all the tested microorganisms. The results of Table 2 also confirm the good activity of compounds 1, 3 and 4. However, at the tested MIC limit of $39.1 \mu \mathrm{g} / \mathrm{ml}$, the inhibitory activity of compounds 1 and 4 was noted on $19(86.4 \%)$ of the 22 tested microorganisms while that of compound 3 was observed on $16(72.7 \%)$. Regarding the degree of activity of the tested samples, the crude extract as well as the compounds isolated could mostly be considered as very potent. The lowest MIC values of $19.5 \mu \mathrm{g} / \mathrm{ml}$ for the crude extract of Dorstenia barteri Bureau is 16-fold greater than the corresponding value $(1.2 \mu \mathrm{g} / \mathrm{ml})$ for both gentamycin and nystatin used as the RA. This lowest MIC value $(19.5 \mu \mathrm{g} / \mathrm{ml})$ was observed with Dorstenia barteri Bureau on seven microorganisms namely Citrobacter freundii, Enterobacter aerogens, Proteus mirabilis, Proteus vulgaris, Bacillus megaterium, Bacillus stearothermophilus and Candida albicans. For the tested compounds, the lowest MIC value $(0.3 \mu \mathrm{g} / \mathrm{ml})$ was obtained only with compound 1, which appeared as the most active principle tested in this study. This lowest value is about 4-fold lower than that of the RA, indicating the powerful and very interesting antimicrobial potential of isobavachalcone (1). This chalcone was more active than the RA on 15 (68.2\%) of the 22 tested microorganisms. The lowest MIC value of 
$1.2 \mu \mathrm{g} / \mathrm{ml}$ observed with compound $\mathbf{3}$ on Enterobacter cloacae, Morganella morganii, Bacillus megaterium and Bacillus stearothermophilus was also lower or equal to that of the RA on the corresponding microorganisms. The corresponding value for compound 4 $(4.9 \mu \mathrm{g} / \mathrm{ml})$ was lower than that of the RA on Enterobacter aerogens. This data support the interesting antimicrobial activity of compounds 1, 3 and $\mathbf{4}$ observed following the disc diffusion test. Compound $\mathbf{5}$ could also be considered as interesting in the perspective of the development of antimicrobial drugs as MIC values were observed on $11(50 \%)$ of the 22 tested microorganisms. This can be confirmed by the results of the MMC determination also reported in Table 2.

These MMC determination results showed that values were obtained with the crude extract of Dorstenia barteri Bureau 20 (90.9\%) of the 22 tested microorganisms, respectively. The MMC's were also obtained with compounds 1 on $16(72.7 \%)$, and compounds 3 and 4 on 14 (63.6\%) of the 22 tested microbial species. However, a keen look of the overall results of Table 2 indicated that the obtained MMC values recorded with each compound was not more than 4-fold greater than their MIC. This indicates that the cidal effects of the tested samples on many of the tested microorganisms could be expected (Carbonnelle et al., 1987).

The results of this study indicate that this plant extract and some of its flavonoids could possibly be used as antibiotics but more in vivo experiments are necessary. The antimicrobial activity of the Dorstenia barteri Bureau may be due to the presence of both antibacterial and antifungal compounds.

Regarding the structure-activity relationship, compounds $\mathbf{1}$ and $\mathbf{4}$ are both active on all the tested microorganisms (Table 1). Nevertheless, compound 1 (lowest MIC value of $0.6 \mu \mathrm{g} / \mathrm{ml}$ ) have more pronounced activities that compound 4 (lowest MIC value of $4.9 \mu \mathrm{g} / \mathrm{ml}$ ) on all the tested microbial cultures (Table 2). Therefore it appeared that addition of the second 3 -isoprenyl group to compound $\mathbf{1}$ (to yield compound $\mathbf{4}$ ) significantly decreased the antimicrobial activity. The cyclisation of compound $\mathbf{1}$ (to give compound 3) also decreases significantly the antimicrobial activity as compound $\mathbf{3}$ is 
active on $16(72.7 \%)$ conversely to compound 1 that appeared to be active on $100 \%$ of the tested microorganisms (Table 2). When looking at the activity of compounds $\mathbf{2}$ and $\mathbf{4}$ [reported in our previous study (Kuete et al., 2007a)], it can also be concluded that the number and the position of the isoprenyl substituents significantly influence the antimicrobial activity of chalcones. Also, this paper demonstrates that the biflavone (compound 5) is less active than the tested chalcones (compound 1-4).

To the best of our knowledge, the antibacterial and the anticandidal activities of Dorstenia barteri Bureau, as well as that of compounds 1, 3, 4 and 5 are being reported for the first time. Nevertheless, this study supports the antimicrobial traditional use of the species and of the genus Dorstenia. However, the good antimicrobial activity of the methanolic extract of Dorstenia angusticornis was previously demonstrated (Kuete et al., 2007a). Also, Stipulin have been shown to be active on both Gram-positive and Gramnegative bacteria and Candida species (Kuete et al., 2007a).

The known antimicrobial mechanisms associated to flavonoids may explain the antimicrobial potency of these compounds from the crude extract. The activity of flavonoids such as compounds might be due to their ability to complex with bacterial cell wall (Cowan, 1999) and therefore, inhibiting the microbial growth.

The present study provides an important basis for the use of extracts from Dorstenia barteri Bureau for the treatment of infections associated to the studied microorganisms. The crude extract as well as the isolated compounds mostly compounds 1, 3 and $\mathbf{4}$ could possibly be useful for the development of new antimicrobial drugs, depending on their in vivo activity. However, pharmacological and toxicity studies currently going on in our laboratory will be necessary to confirm this hypothesis. 


\section{References}

Abegaz et al., 1998 B.M. Abegaz, T.B. Ngadjui, E. Dongo and H. Tamboue, Prenylated chalcones and flavones from the leaves of Dorstenia kameruniana, Phytochemistry 49 (1998), pp. 1147-1150.

Abegaz et al., 2000 B.M. Abegaz, T.B. Ngadjui and M.T. Dongo Bezabih, Chemistry of the Genus Dorstenia, Current Organic Chemistry 4 (2000), pp. 1079-1090.

Abegaz et al., 2004 B.M. Abegaz, T.B. Ngadjui, N.G. Folefoc, S. Fotso, P. Ambassa, B. Merhatibeb, E. Dongo, F. Rise and D. Peterson, Prenylated flavonoids, monoterpenoid furocoumarins and other constituents of the twigs of Dorstenia elliptica (Moraceae), Phytochemistry 65 (2004), pp. 221-226.

Adjanohoun et al., 1996 J.E. Adjanohoun, N. Aboubakar, K. Dramane, M.E. Ebot, J.A. Ekpere, E.G. Enow-Orock, D. Focho, Z.E. Gbile, A. Kamanyi, J. Kamsu Kom, A. Keita, T. Mbenkum, C.N. Mbi, A.L. Mbiele, I.L. Mbome, N.K. Miburu, W.L. Nancy, B. Nkongmeneck, B. Satabie, A. Sofowora, V. Tamze and C.K. Wirmum, Traditional Medicine and Pharmacopoeia: Contribution to Ethnopharmacological and Floristic Studies in Cameroon, OAU/STRC, Lago/Nigeria (1996) p. 299.

Berghe and Vlietinck, 1991 V.A. Berghe and A.J. Vlietinck, Screening Methods for antibacterial and antiviral agents from higher plants, Method for Plant Biochemistry 6 (1991), pp. 47-68.

Bouquet, 1969 Bouquet, A., 1969. Féticheurs et médecine traditionnelle du Congo. Mémoire de l'orstom, Paris.

Bruneton, 1999 Bruneton, J., 1999. Pharmacognosie: Phytochimie, Plantes médicinales, $3^{\text {eme }}$ ed. Tec Doc., Paris, pp. 263-309. 
Carbonnelle et al., 1987 Carbonnelle, B., Denis, F., Marmonier, A., Pinon, G., Vague, R., 1987. Bactériologie médicale: Techniques usuelles. Ed SIMEP, Paris, pp. 228-282.

Cowan, 1999 M.M. Cowan, Plant Products as Antimicrobial Agents, Clinical Microbiology Review 12 (1999), pp. 564-582.

Fukai et al., 1994 T. Fukai, J. Nishizawa and T. Nomura, Five isoprenoid-substituted flavonoids from Glycyrrhiza eurycarpa, Phytochemistry 5 (1994), pp. 515-519.

Goh et al., 1992 H.S. Goh, I. Jantan and G.P. Waterman, Neoflavonoid and biflavonoid constituents of calophyllum inophylloide, Journal of Natural Product 55 (1992), pp. $1415-1420$.

Kuete et al., 2007a V. Kuete, I. Konga Simo, B. Ngameni, D.J. Bigoga, J. Watchueng, R. Nzesse Kapguep, F.-X. Etoa, T.B. Ngadjui and V. Penlap Beng, Antimicrobial activity of the methanolic extract, fractions and four flavonoids from the twigs of Dorstenia angusticornis Engl. (Moraceae), Journal of Ethnopharmacology 112 (2007), pp. 271277.

Kuete et al., 2007b V. Kuete, J.R. Nguemeving, V. Penlap Beng, A.G.B. Azebaze, F.-X. Etoa, M. Meyer, B. Bodo and A.E. Nkengfack, Antimicrobial activity of the methanolic extracts and compounds from Vismia laurentii De Wild (Guttiferae), Journal of Ethnopharmacology 109 (2007), pp. 372-379.

Kuete et al., 2008 V. Kuete, T.A. Mbaveng, M. Tsafack, V. Penlap Beng, F.X. Etoa, A.E. Nkengfack, J.J.M. Meyer and N. Lall, Antitumor, antioxidant and antimicrobial activities of Bersama engleriana (Melianthaceae), Journal of Ethnopharmacology 115 (2008), pp. 494-501.

Marchal et al., 1985 Marchal, N., Bourdon, J.L., Richard, C., 1985. Les Milieux de Culture Pour l'isolement et l'identification Biochimique des Bactéries. Ed DOIN, Paris, p. 89. 
Ngadjui et al., 2000 T.B. Ngadjui, F.S. Kouam, E. Dongo, F.W.G. Kapche and M.B. Abegaz, Prenylated flavonoids from the aerial parts of Dorstenia mannii, Phytochemistry 55 (2000), pp. 915-919.

Ngameni et al., 2007 B. Ngameni, M. Touaibia, A. Belkaid, P. Ambassa, J. Watchueng, R. Patnama, T.B. Ngadjui, B. Annabi and R. Roya, Inhibition of matrix metalloproteinase-2 secretion by chalcones from the twigs of Dorstenia barteri Bureau, Arkivoc 9 (2007), pp. 91-103.

Shih et al., 2004 C.C. Shih, K.L. Han and H.K. Yueh, Two new compounds from the leaves of calocedrus microlepic var. formosana, Chemical and Pharmaceutical Bulletin 52 (2004), pp. 762-7563.

Tereschuk et al., 1997 M.L. Tereschuk, M.V.Q. Riera, G.R. Castro and L.R. Abdala, Antimicrobial activity of flavonoid from leaves of Tagetes minuta, Journal of Ethnopharmacology 56 (1997), pp. 227-232.

Thomas et al., 1989 Thomas, D.W., Thomas, J.M., Bromely, W.A., Mbenkum, F.T., 1989. Korup Ethnobotany Survey. W.W.F. Survey, p. A31.

Tsopmo et al., 1999 A. Tsopmo, M. Tene, P. Kamnaing, J.F. Ayafor and A. Sterner, A new Diels-Alder type adduct flavonoids from D. barteri, Journal of Natural product 62 (1999), pp. 1432-1434.

Zgoda and Porter, 2001 J.R. Zgoda and J.R. Porter, A convenient microdilution method screening natural products against bacteria and fungi, Pharmaceutical Biology 39 (2001), pp. 221-225. 
Corresponding author at: Department of Organic Chemistry, University of Yaoundé I, P.O. Box 812, Yaoundé, Cameroon. Tel.: +237 758661 91; fax: +237 22221090.

Corresponding author at: Department of Biochemistry, University of Yaoundé I, P.O. Box 812, Yaoundé, Cameroon. Tel.: +237 754689 27/77 3559 27/75 3384 55; fax: +23722226018 . 